\title{
Characterization of Arsenic and Uranium Pollution Surrounding a Uranium Mine in Southwestern China and Phytoremediation Potential
}

\author{
Ruofei Li, Faqin Dong*, Gang Yang**, Wei Zhang, Meirong Zong, Xiaoqin Nie, \\ Lei Zhou, Asma Babar, Jinfeng Liu, Bhagat Kanwar Ram, Chengjie Fan, Yun Zeng \\ Key Laboratory of Solid Waste Treatment and Resource Recycling, Ministry of Education,School of Life Science and \\ Engineering, Southwest University of Science and Technology, Mianyang, P.R. China
}

Received: 6 December 2018

Accepted: 29 January 2019

\begin{abstract}
Heavy metal pollution by both uranium and arsenic has become a major environmental problem associated with uranium mining worldwide. At present, physical, chemical and biological technologies are available as the main remediation techniques. Among them, phytoremediation is relatively low cost, hinders more pollution and allows for fast recycling of the uranium as compared to other techniques. However, suitable phytoremediation depends critically on the better choice of plant species. In this study, field sampling of soils and plants surrounding a uranium mine was conducted, and atomic emission spectrometry of samples performed, in order to characterize the distribution of heavy metal pollution and to provide a scientific basis for the phytoremediation of uranium mining sites. Soil uranium concentrations were found to be highest in open-pit mine sites, followed by ore dressing investigation sites and also the river confluence sites. Uranium did not migrate from active mining areas and the highest uranium concentration measured $232.70 \mathrm{mg} \times \mathrm{kg}^{-1}$. In contrast, arsenic regularly migrated downstream, with soil concentrations averaging $47.26 \mathrm{mg} \times \mathrm{kg}^{-1}$, two times the limit set by the Three Grade Standard of Soil Quality in China (GB 15618-1995). Rumex nepalensis accumulated high levels of uranium, with a bioconcentration factor of 3.60 and a transfer factor of 3.61. Polygonum viviparum was able to accumulate arsenic, with a root transfer factor of 3.69 , and also uranium as indicated by a bioconcentration factor greater than one. Thus, our investigations improved the understanding of the potential role of Polygonum viviparum and Rumex nepalensis involved in phytoremediation of uranium or uranium-arsenic pollution.
\end{abstract}

Keywords: uranium, arsenic, mine tailings, phytoremediation, plant screening

\footnotetext{
*e-mail: fqdong@swust.edu.cn

**e-mail: yanggang903@163.com
} 


\section{Introduction}

The nuclear industry has accelerated global demand for uranium (U). During the past 60 years, uranium has become one of the world's most important energy minerals [1]. However, uranium mining originates at the cost of ecological destruction and environmental pollution. Waste products from uranium mining contain many harmful metals [2]. Plants uptake and accumulate these metals from polluted soil, and these toxic products are potentially harmful to animals and human beings via the food chain [3]. Pollution containing uranium-arsenic complexes are a particular cause of anxiety demanding special measures to remediate [4]. Uranium can cause cancer in animals because of its chemical toxicity and radiation production [5]. Arsenic (As) is a toxic element often found in uranium mines [6]. Compared to other remediation methods, such as physical fixation and chemical leaching, phytoremediation (i.e., the use of living plants to remove pollutants) is relatively low cost, simple to implement and does not produce any secondary effect of pollution [7]. Phytoremediation can also promote the reestablishment of diverse plant and arthropod communities [8]. Therefore, phytoremediation is preferred by researchers all around the world [9].

The development of phytoremediation technology is still in its infancy, and a number of challenges remain to be solved [10]. For example, the spatial distribution of heavy metals can strongly influence the distribution of susceptible plant species in mine-polluted environments [11]. Metal concentrations tend to affect the distribution of herbaceous species more strongly than those of woody species in serpentine soils [12]. However, trace metals in the soil are not a single force affecting the distribution of supper accumulator plant species, but soil properties, climatic factors, and human activities are also key factors in this scenario [13]. Soil-moisture may be a significant factor influencing vegetation type in herbaceous communities [14]. The distributions of hyper-accumulator plant species are thought to closely correlate with soil pollution.

By using lab tests, duckweed has been shown to reduce uranium concentrations ranging from $300 \mu \mathrm{g} \times \mathrm{L}^{-1}$

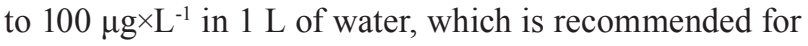
maximum allowable concentrations [15]. The Edenspace Company carried out a pilot phytoremediation project for uranium-polluted soils in the United States Army Aberdeen Weaponry Test Site from 1997-1999. The project found that the remediation of uraniumcontaminated soils by planting hyper-accumulator species was a cost-effective and environmentally friendly method [16]. Such phytoremediation has also been used to remediate arsenic-polluted mine soils. Centipede grass acts as an arsenic supper accumulator, with accumulated arsenic accumulation accounting for up to $2.3 \%$ of a plant's biomass [17]. Similarly, sea poppy species were used successfully to remediate arsenic-polluted soils surrounding a silver mine in Turkey [18]. However, most examples of arsenic and uranium phytoremediation to date originated from greenhouse or pilot studies only - not from natural areas polluted by mine tailings.

Heavy metals are elements with high metallic properties with atomic numbers above 20, that of sodium [19]. The most common heavy metal contaminants are $\mathrm{Cd}, \mathrm{Cr}, \mathrm{Hg}, \mathrm{Pb}, \mathrm{Cu}, \mathrm{Zn}$, and $\mathrm{As}$ [20]. Heavy metals can enter the environment both naturally and anthropogenically. The major production causes are anthropogenic sources, specifically mining exploration [21]. The accumulation of heavy metals often leads to soil degradation and ecosystem failure. Heavy metals can be released into food chains via polluted water, air and soil, and consequently cause food contamination, therefore producing a threat to human and animal health [22]. Heavy metal pollution is a global problem that needs the combined efforts of scientists, governments, and communities [23]. Different methods, such as geoaccumulation index (Igeo), pollution load index (PLI), biogeochemical index (BGI), enrichment factor (EF) and potential risk index, have been widely used to assess the contamination level of heavy metals in industrial sites [24-28]. Luo et al. (2014) have investigated heavy metals pollution in soils from the study zones by pollution load index (PLI). According to their studies, elements $\mathrm{Sr}, \mathrm{Cu}, \mathrm{Ni}, \mathrm{Pb}$ and $\mathrm{Zn}$ environmental risk occurred in the Zoige uranium mine [29]. However, no information concerning the assessment of uranium and arsenic ecological risk has been found in the literature.

The Zoige uranium mine, located in southwestern China, has been the site of extensive research into mineral resources and geological prospecting. Peng et al. examined vegetation growing on mine tailings using a ground-based spectrometer. Results show that the red edge of the vegetation was blue-shifted, indicating heavy metal pollution in soils and plants near the heap of the $U$ mine [30]. In recent years, a little attention has been directed toward the remediation of As- and U-polluted areas, as well as toward heavy-metal tolerant plant species. Elymus dahuricus can tolerate high copper concentrations [31], while Polygonum viviparum was used to phytoremediate the Zoige peat areas [32].

The objective of this study was to screen plant species for their ability to rehabilitate As- and U-contaminated soils in former uranium mining or milling sites [33]. In order to improve efficiency in screening potential accumulator species for phytoremediation, it may be helpful to know the identity of species growing in polluted areas. In this study, (1) the migration potential of arsenic and uranium was assessed and their distributions mapped, and (2) the accumulation potential and distributions of plant species in polluted areas were examined in order to choose which plant species may be best suited for remediation efforts. 


\section{Materials and Methods}

\section{Description of the Study Area and Sample Sites}

The Zoige uranium mine is located in China's southwestern Sichuan Province. The area surrounding the mine experiences a sub-humid climate typical of the plateau, with an average annual precipitation of 900 $\mathrm{mm}$ falling predominantly from July to September; the temperature ranges from a low of $-26^{\circ} \mathrm{C}$ to a high of $29^{\circ} \mathrm{C}$. This area also comprises a highly promising and valuable uranium resource base for China, with more than 10 uranium deposits and 20 ore deposits discovered to date [34].

The study area included an open-pit mine, an area of artificial remediation and sites along the $\mathrm{Z}$ river, as well as several ore-dressing sites along the $\mathrm{Y}$ river. Finally, the $\mathrm{S}$ river, a confluence of the $\mathrm{Y}$ and $\mathrm{Z}$ rivers. To evaluate the level of heavy metal contamination in soils and the remediation capability of tolerant plant species in the mine-polluted area, a variety of soil and plant samples were collected from the study area in 2017. Some sample plants of Rumex nepalensis (R) and Polygonum viviparum $(\mathrm{P})$ were listed in $\mathrm{Y}$ and $\mathrm{Z}$ rivers
(Fig. 1). All mining activity took placed upstream on the rivers, as shown in Fig. 1, which means that poor management of mine waste products can potentially create a serious environmental hazard for downstream ecosystems, as well as for nearby living human beings.

\section{Plant and Soil Sampling and Analysis}

The GPS coordinates of all sample points were recorded (Columbo A6Gps) and a portable radiometer (FD3013 gamma-ray detector/gamma radiometer) was used to measure gamma radiation at each point. Herbaceous plant samples included both below- and above-ground plant parts. Shrubs were sampled by cutting off small twig pieces. Soil samples included the soil layers from 0 to $20 \mathrm{~cm}$ deep and all the samples were transported to a laboratory. Plant samples were first chopped into small pieces, dried at $70^{\circ} \mathrm{C}$ and then ground to powder. Soil samples were air-dried at room temperature and then all the samples were passed through a 100 -mesh screen.

Soil metallic elements were quantified following the method of Zhang et al. (2007). A $0.1 \mathrm{~g}$ soil sample was first incubated with a mixture of $7 \mathrm{~mL}$ of nitric acid, $2 \mathrm{~mL}$ of hydrofluoric acid and $1 \mathrm{~mL}$ of hydrogen
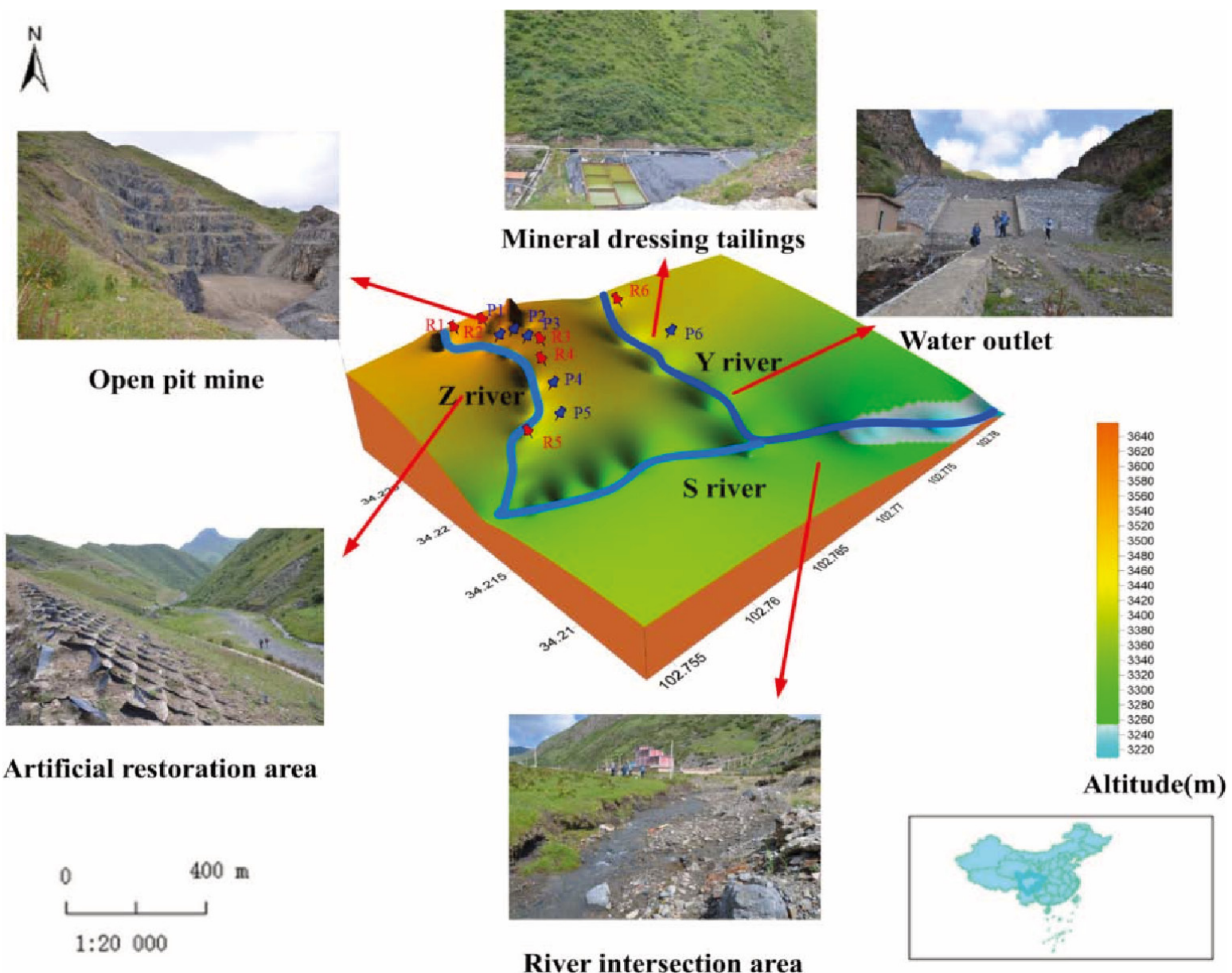

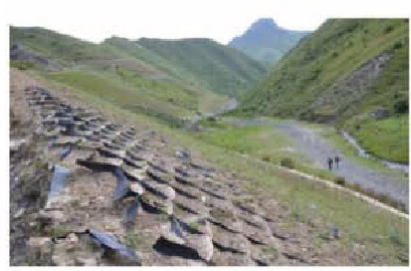

Artificial restoration area

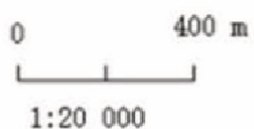

\section{River intersection area}

Fig. 1. Sample area in the Zoige uranium ore field, China (Note: R1 to R6 indicate sample sites for Rumex nepalensis; P1 to P6 indicate sample sites for Polygonum viviparum). 
peroxide in a polytetrafluoroethylene (PTFE) digestion tank at $180^{\circ} \mathrm{C}$ for half an hour. The PTFE digestion tank was then placed in a microwave digest system (Anton Paar Multiwave PRO), where the sample was digested at $140^{\circ} \mathrm{C}$ and $200^{\circ} \mathrm{C}$ for $30 \mathrm{~min}$, respectively. After digestion, $1 \mathrm{~mL}$ of perchlorate and $2 \mathrm{~mL}$ of nitric acid were added to dissolve solids. Samples were then washed with $5 \mathrm{~mL}$ of distilled water before diluting to a final volume of $25 \mathrm{~mL}$ in a volumetric flask [35].

Determining As and $U$ concentrations in plant tissues followed by Zhong et al., (2016), starting with $0.2 \mathrm{~g}$ of each plant sample and incubating overnight in a PTFE tank with $10 \mathrm{~mL}$ of nitric acid. The tank contents were then supplemented with $2 \mathrm{~mL}$ of hydrogen peroxide and heated to $180^{\circ} \mathrm{C}$ in a graphite digestion instrument (SH220) for roughly half an hour until only 2-3 mL of solution remained. Samples were washed with $10 \mathrm{~mL}$ of distilled water and stored in $50 \mathrm{~mL}$ polypropylene tubes [36]. After sample preparation, the arsenic and uranium concentrations in both plant and soil samples were determined using electron-coupled plasma emission spectrometry (iCAP6500). This method is relatively cheap and high in efficiency, with a detection limit of $10 \mathrm{ug} \times \mathrm{L}^{-1}$.

\section{Environmental Risk Assessment}

The coefficient of variation $(\mathrm{CV})$, was calculated as follows [37]:

$$
\begin{gathered}
\mathrm{CV}=\sigma / \overline{\mathrm{x}} \\
\sigma=\sqrt{\frac{1}{\mathrm{~N}} \mathrm{i}_{\mathrm{i}=1}^{\mathrm{N}}\left(\mathrm{x}_{\mathrm{i}}-\overline{\mathrm{x}}\right)^{2}}
\end{gathered}
$$

...where $\mathrm{x}_{\mathrm{i}}$ represents the metal concentration $\left(\mathrm{mg} \times \mathrm{kg}^{-1}\right)$ in a soil sample and $-x$ represents the average metal concentration $\left(\mathrm{mg} \times \mathrm{kg}^{-1}\right)$ in the study area soils. After calculating $\mathrm{CVs}$ for each soil heavy metal in this study, the spatial variability in each analysis was rated: a $\mathrm{CV}<10 \%$ was classified as low variability, $10 \%<\mathrm{CV}<100 \%$ moderate variability and a $\mathrm{CV}>100 \%$ high variability.

According to Huang and Jin., (2008), a single factor index $(\mathrm{Pi})$ can be used to quantify the extent of heavy metal accumulation in soils:

$$
\mathrm{P}_{\mathrm{i}}=\mathrm{C}_{\mathrm{i}} / \mathrm{C}_{0}
$$

...where $\mathrm{C}_{\mathrm{i}}$ is the measured concentration of the heavy metal $\left(\mathrm{mg} \times \mathrm{kg}^{-1}\right)$ in a sample and $\mathrm{C}_{0}$ is the background concentration of the same element in the study area $\left(\mathrm{mg} \times \mathrm{kg}^{-1}\right) . \quad \mathrm{A} \quad \mathrm{P}_{\mathrm{i}} \leq 1$ indicates that a soil sample is unpolluted, while $1<\mathrm{P} \leq 2$ indicates slight pollution, $2<\mathrm{P}_{\mathrm{i}} \leq 3$ light pollution, $3<\mathrm{P}_{\mathrm{i}} \leq 5$ moderate pollution and $\mathrm{P}_{\mathrm{i}} \geq 5$ heavy pollution [38].

An environmental risk assessment measure of heavy metal pollution [39], the pollution load index (PLI), is often used to characterize spatial trends in heavy metal pollution:

$$
\mathrm{PLI}=\left(\mathrm{CF}_{1} \times \mathrm{CF}_{2} \times \mathrm{CF}_{3} \times \ldots \mathrm{CF}_{\mathrm{n}}\right)^{1 / \mathrm{n}}
$$

All ionic concentrations are expressed in $\mathrm{mg} \times \mathrm{kg}^{-1}$ and $\mathrm{CF}$ is the ratio between the measured content of each metal to its background value in sediment, i.e., $\mathrm{CF}=\mathrm{C}_{\text {(metal) }} / \mathrm{C}_{\text {(background) }}\left(\mathrm{mg} \times \mathrm{kg}^{-1}\right)$. The $\mathrm{CF}$ values are categorized into four, where: $\mathrm{CF}<1$ indicates low contamination, $1 \leq \mathrm{CF}<3$ is moderate contamination, $3 \leq \mathrm{CF}<6$ is considerable contamination, and $\mathrm{CF}>6$ is very high contamination. A site value of $0 \leq \mathrm{PLI}<1$ was considered to be unpolluted, while $1 \leq \mathrm{PLI}<2$ was considered lightly polluted, $2 \leq \mathrm{PLI}<3$ moderately polluted and $P L I \geq 3$ highly polluted. Moderately to highly polluted $(3 \leq \mathrm{PLI}<4)$, highly polluted $(4 \leq \mathrm{PLI}<5)$, or very highly polluted (PLI $\geq 5)$.

\section{Identification and Analysis of Arsenic and Uranium in Plant Samples}

Most plant species found in the study area were strictly wild alpine species. Samples from observed plant species were collected in November 2017 and then dried. Plant species were identified using relevant literature, picture comparisons and software, because regional differences occurred for some species names.

For both arsenic and uranium, the bioconcentration factor (BCF) and transfer factor (TF) were calculated for each plant sample. The bioconcentration factor measured the tendency for a metal pollutant accumulation in plants, and it was calculated as $\mathrm{BCF}=\mathrm{C}$ (root) $/ \mathrm{C}$

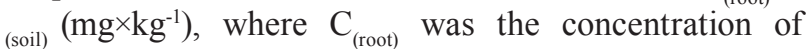
the targeted metal in a plant root sample and $\mathrm{C}_{\text {(soil) }}$ was the background concentration of the metal in the soil [40]. The transfer factor was the ratio of metal concentrations in the plant shoots versus roots, i.e., $\mathrm{TF}=\mathrm{C}_{\text {(shoot) }} / \mathrm{C}_{\text {(root) }}\left(\mathrm{mg} \times \mathrm{kg}^{-1}\right)$, where $\mathrm{C}_{\text {(shoot) }}$ was the metal concentration in the shoots and $\mathrm{C}_{\text {(root) }}$ the concentration in the roots [41].
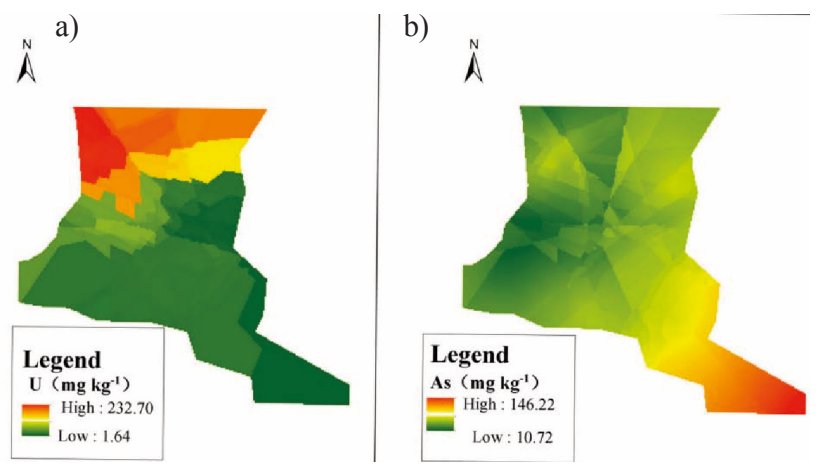

Fig.2. Heat map of soil arsenic and uranium concentrations $\left(\mathrm{mg} \cdot \mathrm{kg}^{-1}\right)$ across the sample region created using ArcGIS software: a) uranium concentrations in the study area $\left(\mathrm{mg}^{\mathrm{kg}} \mathrm{kg}^{-1}\right)$ and b) arsenic concentrations in the study area $\left(\mathrm{mg} \cdot \mathrm{kg}^{-1}\right)$. 


\section{Statistical Analyses}

Data was analyzed using SPSS 22, Microsoft Word and Excel. The spatial distributions of arsenic and uranium pollution, as well as plant species distributions, were determined by using a geographical information systems (GIS) software package. The 3D geological model in Fig. 1 was drawn using Surfer.

\section{Results and Discussion}

\section{Characterization of Arsenic and Uranium Soil Contamination}

\section{Arsenic and Uranium Distribution}

Arsenic and uranium contamination in the study area is illustrated by using a red-green color key (Fig. 2). The $U$ distribution was depicted in Fig. 2(a). Soils surrounding the open-pit mine and artificial restoration area contained significant amounts of uranium, reaching up to $232.70 \mathrm{mg} \times \mathrm{kg}^{-1}$. Uranium concentrations were highest in soils surrounding the open-pit mine, followed by the mineral covering the investigation site and ultimately the river intersection. In addition, uranium concentrations were lower downstream than the upstream of the $\mathrm{Y}$ and $\mathrm{Z}$ rivers. This could be attributed to the concrete walls of the tailings dam, which may reduce the risk of uranium migrating toward the downstream (Fig. 1). Soil arsenic concentrations covering the study area ranged from $10.72 \mathrm{mg} \times \mathrm{kg}^{-1}$ to $146.22 \mathrm{mg} \times \mathrm{kg}^{-1}$. In contrast to $\mathrm{U}$, arsenic migration toward the downstream was in abundance on the S river (Fig. 2(b)). The observed levels of As and U contamination may also be affected by external factors such as mine development, ore-stacking and mineral processing (Fig. 2).

\section{Assessment of Arsenic and Uranium Pollution}

An overview of arsenic and uranium contamination in mine surface soils was presented in Table 1. Soil As and $U$ concentrations averaged $44.39 \mathrm{mg} \times \mathrm{kg}^{-1}$ and

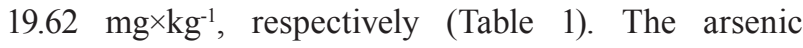
concentration in mine soils was not only four times higher than average for Chinese brown soils, but also double to more than the environmental target level set by the Chinese Environmental Quality Standards for Soils (GB 15618-1995). The standard deviations of the mean arsenic and uranium concentrations were similar, at $31.96 \mathrm{mg} \times \mathrm{kg}^{-1}$ and $39.79 \mathrm{mg} \times \mathrm{kg}^{-1}$, respectively. In the study area near the Zoige uranium mine, the large CV for U (198\%) indicated that the concentration of $\mathrm{U}$ fluctuated more than other sites, while the $\mathrm{CV}$ of As $(72 \%)$ indicated a moderate degree of variability (Table 1). The single factor index $\left(\mathrm{P}_{\mathrm{i}}\right)$ revealed moderate arsenic pollution in soils $\left(1<\mathrm{P}_{\mathrm{i}} \leq 2\right)$, but the pollution load index (PLI) indicated light arsenic pollution $(1 \leq \mathrm{PLI}<2)$. For uranium, both $\mathrm{P}_{\mathrm{i}}$ and PLI indicated heavy uranium pollution ( $\mathrm{P}_{\mathrm{i}} \geq 5$ and $\mathrm{PLI} \geq 3$ ).

\section{Comparisons with Previous Studies}

Uranium concentrations in unpolluted soils have been reported to range from $1.90 \mathrm{mg} \times \mathrm{kg}^{-1}$ to $4.40 \mathrm{mg} \times \mathrm{kg}^{-1}$ worldwide [42]. But the $\mathrm{U}$ concentrations found in this study were higher than previous data reported for unpolluted soils in China (Table 1). It indicated that contamination occured due to mining activities in Zoige (Fig. 2). Several studies have found similar mine-associated contamination and have correlated uranium abundance with radioactivity levels [43]. However, U concentrations were not found to co-vary with As concentrations in space. In addition, arsenic migration downstream on the $\mathrm{S}$ river, reaching high levels at downstream peat swamp [44]. This may be due to the high clay content of fine-grained sediments in the peat swamp that potentially increases the arsenic absorption [45]. Another possibility is that high arsenic levels are correlated with large quantities of dissolved organic matter or other geological factors, such as plant decomposition or sediment depositions [46].

\section{Phytoaccumulation of Arsenic and Uranium}

\section{Characterization of Arsenic and Uranium Accumulation in Plants}

Twenty-four different plant species, including Leontopodium dedekensii, Polygonum viviparum and Gentiana straminea, were identified from the collected samples (Table 2). The composition of plant communities was relatively simple, and three endemic Chinese plant species were identified: Anaphalis lactea, Artemisia divarica and Cremanthodium lineare. The dominant herb families included Compositae,

Table1. Arsenic and uranium pollution in the study area.

\begin{tabular}{|c|c|c|c|c|c|c|}
\hline Metal & Mean $\left(\mathrm{mg} \cdot \mathrm{kg}^{-1}\right)$ & $\mathrm{SD}\left(\mathrm{mg} \cdot \mathrm{kg}^{-1}\right)$ & $\mathrm{CV}$ & Background $\left(\mathrm{mg} \cdot \mathrm{kg}^{-1}\right)$ & $\overline{\mathrm{P}} \mathrm{i}$ & PLI \\
\hline As & 44.39 & 31.96 & $72 \%$ & 9.20 & 4.82 & 1.64 \\
\hline $\mathrm{U}$ & 19.62 & 39.79 & $198 \%$ & 2.79 & 7.03 & 6.31 \\
\hline
\end{tabular}

SD: Standard deviation CV: Coefficient of variation $\bar{P}$ i: Single factor pollution index PLI: Pollution load index

Background values were obtained from the literature (National Environmental Protection Bureau. Background value of soil elements in China [M]. China Environmental Science Press, 1990.). 
Polygonum and Gentianaceae, while the next most common species belonged to Leguminosae, Gramineae and Ranunculaceae. Berberis polyantha, Hippophae rhamnoides, Rhododendron zheguense, Rhododendron atropunicum, Spiraea mongolica, Salix zhegushanica, and Platycladus orientalis were found as short shrub species. The most common shrub species were Rhododendron zheguense, Salix zhegushanica, and Spiraea mongolica, which belonged to the Ericaceae, Rosaceae and Salicaceae, respectively (Table 2).

The concentration of uranium was much higher in sample plant roots than shoots (Fig. 3a). By comparing plant species, much higher uranium concentrations were found in Rumex nepalensis,

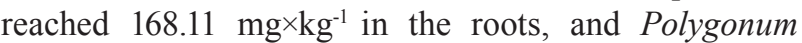
viviparum at $73.20 \mathrm{mg} \times \mathrm{kg}^{-1}$. Other plant species also showed higher rates of accumulation of U: Spiraea mongolica (49.58 $\left.\mathrm{mg} \times \mathrm{kg}^{-1}\right)$, Saussurea decurrens (37.11 mg $\left.\times \mathrm{kg}^{-1}\right)$, Anaphalis lactea (35.29 $\mathrm{mg} \times \mathrm{kg}^{-1}$ ) and Salix zhegushanica $\left(28.10 \mathrm{mg} \times \mathrm{kg}^{-1}\right)$. The plant species with the highest $\mathrm{U}$ concentrations in their shoots were: Polygonum viviparum (29.76 $\mathrm{mg} \times \mathrm{kg}^{-1}$ ), Anaphalis lactea

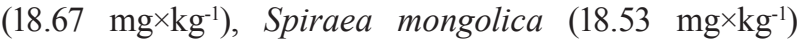
and Elymus dahuricus (14.09 $\left.\mathrm{mg} \times \mathrm{kg}^{-1}\right)$ (Fig. 3b). The highest arenic concentration in roots, averaging $50.88 \mathrm{mg} \times \mathrm{kg}^{-1}$, was found in Artemisia divarica, followed by Elymus dahuricus with $21.24 \mathrm{mg} \times \mathrm{kg}^{-1}$

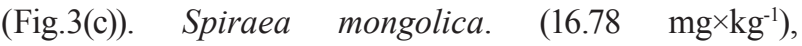

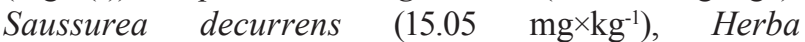
artimisiae $\left(14.97 \mathrm{mg} \times \mathrm{kg}^{-1}\right)$, Polygonum viviparum

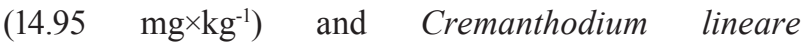
$\left(11.15 \mathrm{mg} \times \mathrm{kg}^{-1}\right)$ in roots. Arsenic concentration in

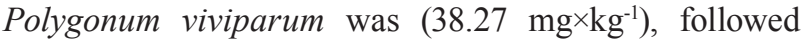
by Saussurea decurrens and Cremanthodium lineare, which contained $10.15 \mathrm{mg} \times \mathrm{kg}^{-1}$ and $10.11 \mathrm{mg} \times \mathrm{kg}^{-1}$ of As in shoots, respectively (Fig. 3d). Arsenic concentrations in the other tested plant species were relatively lower

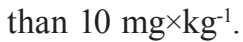

All the plant species identified in the study area were cold-resistant and impervious to heavy metals (Table 2). Species belonging to Compositae, Gentianaceae and Polygonaceae have been reported to have high radiation resistance and antioxidant properties [47]. Plant species have previously been categorized based on their capacity to accumulate uranium in their tissues as follows: super accumulators (average $U$ concentration greater than $\left.100 \mathrm{mg} \times \mathrm{kg}^{-1}\right)$, high accumulators (10-100 mg $\left.\times \mathrm{kg}^{-1}\right)$, moderate accumulators $\left(1-10 \mathrm{mg} \times \mathrm{kg}^{-1}\right)$

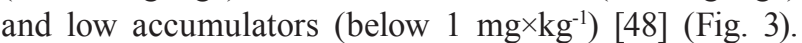
Using these classifications, Rumex nepalensis, a super accumulator, was potentially useful for the remediation of slightly to moderately uranium-contaminated soils [49]. Meanwhile, Anaphalis lactea, Saussurea decurrens and Polygonum viviparum were high accumulators; Gentiana straminea and Rhododendron zheguense were moderate accumulators; and Leontopodium dedekensii was a low accumulator. Frequent studies of $U$ accumulation in these plant species make them promising to be used as phytoremediators [50]. Some
Table 2. List of plant species and associated families identified in the study area.

\begin{tabular}{|c|c|}
\hline Species name & Subject \\
\hline Artemisia divarica & Composite \\
\hline Anaphalis lactea & Composite \\
\hline Astragalus handelii & Leguminous \\
\hline Anemone rivularis & Ranunculus \\
\hline Berberis polyantha & Berberid \\
\hline Cirsium japonicum & Composite \\
\hline Cremanthodium lineare & Composite \\
\hline Elymus dahuricus & Grasses \\
\hline Gentiana straminea & Gentianke \\
\hline Gentiana veitchiorum & Gentianke \\
\hline Herba Artimisiae & Composite \\
\hline Hippophae rhamnoides & Elaeagnus \\
\hline Leontopodium dedekensii & Composite \\
\hline Lomatogonium rotatum & Gentianke \\
\hline Platycladus orientalis & Cupressaceae \\
\hline Potentilla anserine & Rosaceae \\
\hline Polygonum viviparum & Polygonum \\
\hline Saussurea decurrens & Composite \\
\hline Spiraea mongolica & Rosaceae \\
\hline Salix zhegushanica & Salicaceae \\
\hline Rhododendron atropunicum & Ericaceous \\
\hline Rhododendron zheguense & Ericaceous \\
\hline Rumex nepalensis & Polygm \\
\hline
\end{tabular}

shrub species also have the ability to accumulate high U concentrations (Fig. 3); this may be due to their root penetration into bedrock, which increases exposure to uranium [51]. None of the tested plant species had high arsenic concentrations that can be considered as super accumulators [52]. However, the ability of these plants to translocate and accumulate As to a lesser degree may still be useful for phytostabilization [53].

\section{Comparison of Arsenic and Uranium Accumulation in Plants}

The BCF and TF were calculated for $\mathrm{U}$ in plant samples, and index values were shown in Table 3. An average bioconcentration factor (BCF) of greater than one was found for the following plant species: Gentiana straminea (10.88), Lomatogonium rotatum (7.66), Rumex nepalensis (3.60), Spiraea mongolica (3.47), Anaphalis lactea (2.81), Polygonum viviparum (2.02) and Cirsium japonicum (1.47). Similarly, an average transfer factor (TF) of greater than one was found for the following 


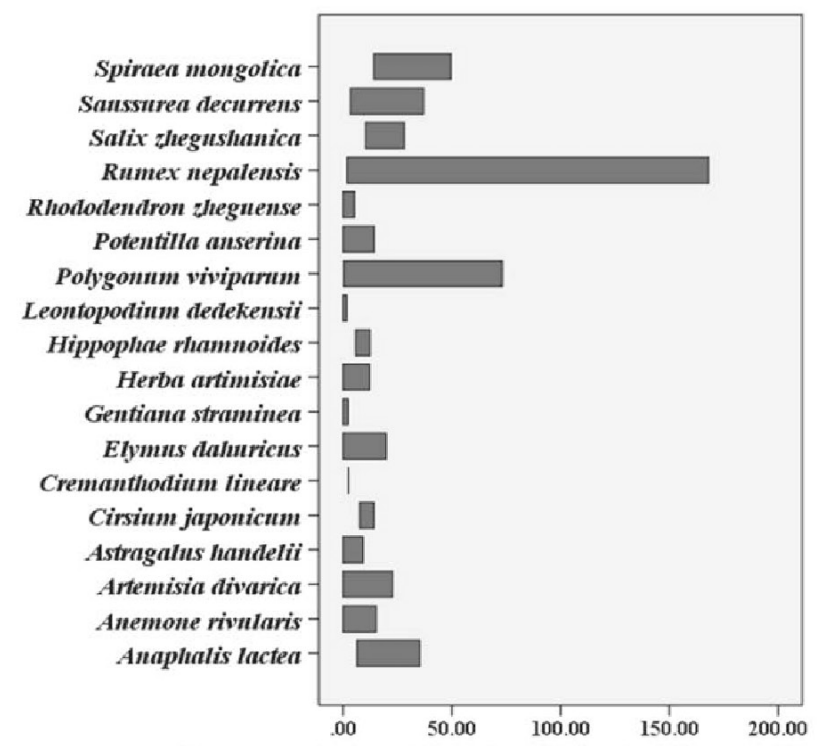

c)

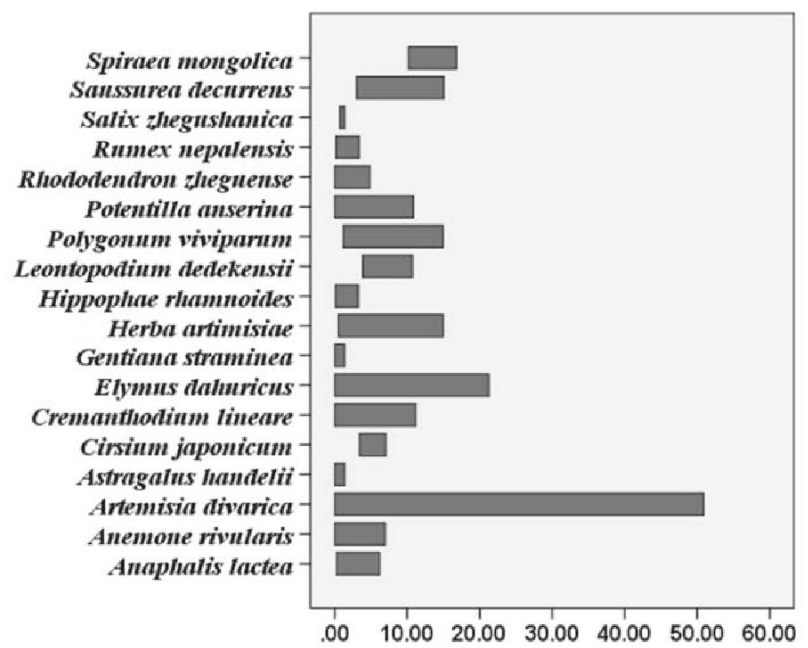

The concentration of arsenic in plant root(mg.kg-1)

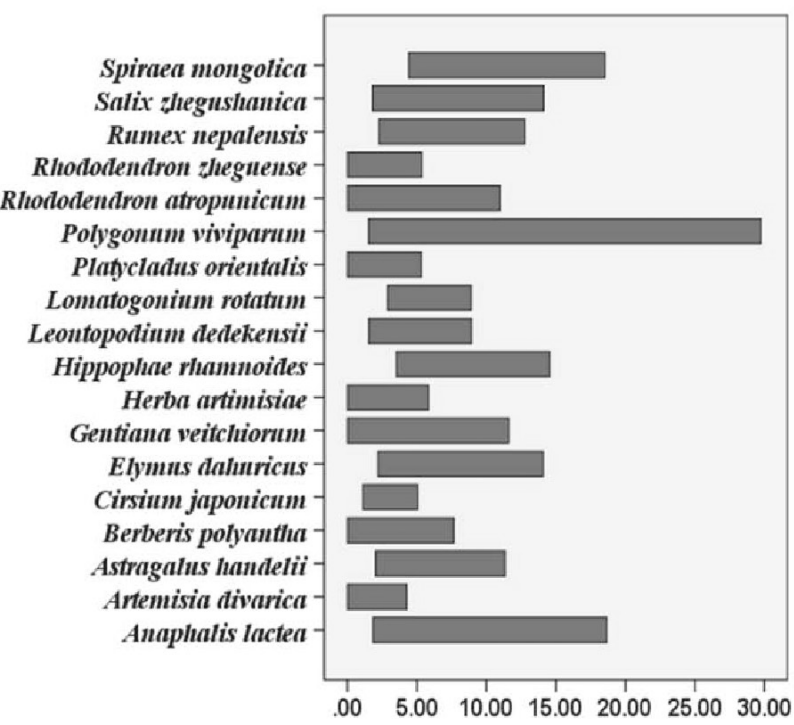

The concentration of uranium in plant aerial part(mg.kg-1) d)

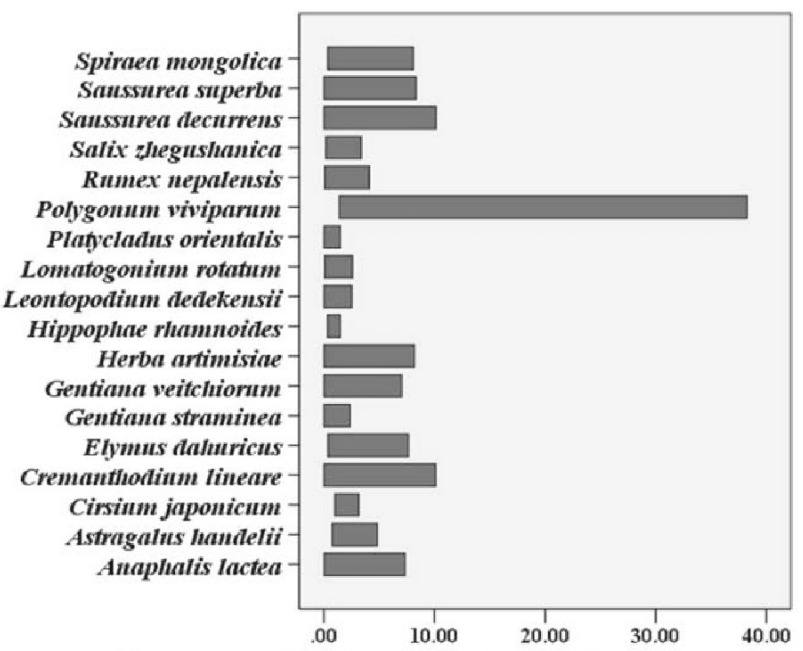

The concentration of arsenic in plant aerial part(mg.kg-1)

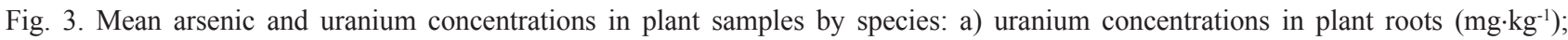
b) uranium concentrations in plant shoots, $\left(\mathrm{mg} \cdot \mathrm{kg}^{-1}\right)$; c) arsenic concentrations in plant roots $\left(\mathrm{mg} \cdot \mathrm{kg}^{-1}\right)$; and d) arsenic concentrations in plant shoots $\left(\mathrm{mg} \cdot \mathrm{kg}^{-1}\right)$.

species: Salix zhegushanica (8.22), Rumex nepalensis (3.61), Hippophae rhamnoides (1.62) and Herba artimisiae (1.44) (Table 3). The highest BCF (around one) was found in Leontopodium dedekensii, followed by Polygonum viviparum and Cirsium japonicum, which had BCFs close to 0.5 , indicating arsenic pollution. The plant species with $\mathrm{TF}>1$ were Herba artimisiae (5.25), Polygonum viviparum (2.04), Salix zhegushanica (1.53), Rumex nepalensis (1.23) and Anaphalis lactea (1.07). In addition, the maximum arsenic $\mathrm{TF}$ observed ranged across species from 0.1 to 30.52 (Table 4).

The $\mathrm{BCF}$ and $\mathrm{TF}$ values play an essential role in determining the ability of a species to remove heavy metals from contaminated soils (Table 3). Plant species with index values (BCF and $\mathrm{TF}$ ) of greater than one can absorb heavy metals from the soil. Furthermore, plant species with $\mathrm{BCF}>1$ and $\mathrm{TF}<1$ can accumulate high concentrations of metals in their roots [54]. As concerns uranium, plant species with $\mathrm{BCF}>1$ may act as accumulators and even supper accumulators can be used for $\mathrm{U}$ removal from the soil [55]. In this study, only Rumex nepalensis had both a BCF and TF very high concentrations of $\mathrm{U}$ in both roots and shoots [56]. Transfer factors varied from species to species. Accumulation of $U$ in shoots and leaves can produce some of the strongest toxic effects in plants due to the impact on photosynthesis, indicating that plants with high $U$ concentrations in their aboveground parts are incredibly tolerant of $U$ pollution [57]. Plant species with relatively higher $\mathrm{BCF}$ for arsenic hold promise for phytoextraction and, consequently, for in situ bioremediation of arsenic-polluted areas [58] (Table 4). 
Table 3. Characterization of uranium accumulation in plant samples.

\begin{tabular}{|c|c|c|c|c|c|c|c|c|}
\hline \multirow{2}{*}{ Plant species } & \multicolumn{4}{|c|}{ BCF } & \multicolumn{4}{|c|}{ TF } \\
\cline { 2 - 10 } & $\mathrm{N}$ & Min & Max & Mean & N & Min & Max & Mean \\
\hline Anaphalis lactea & 8 & 0.15 & 14.87 & 2.81 & 4 & 0.28 & 1.54 & 0.94 \\
\hline Cirsium japonicum & 5 & 0.10 & 5.21 & 1.47 & 2 & 0.08 & 0.66 & 0.37 \\
\hline Elymus dahuricus & 2 & 0.08 & 1.57 & 0.82 & 1 & & 0.48 & \\
\hline Gentiana straminea & 2 & 10.55 & 11.20 & 10.88 & 1 & & 0.94 & \\
\hline Herba Artimisiae & 4 & 0.29 & 1.28 & 0.73 & 2 & 0.86 & 2.02 & 1.44 \\
\hline Hippophae rhamnoides & 4 & 0.11 & 0.89 & 0.37 & 5 & 0.99 & 2.51 & 1.62 \\
\hline Lomatogonium rotatum & 2 & 5.42 & 9.89 & 7.66 & 1 & & 0.55 & \\
\hline Polygonum viviparum & 8 & 0.09 & 4.52 & 2.02 & 6 & 0.05 & 0.78 & 0.48 \\
\hline Rumex nepalensis & 3 & 0.06 & 10.67 & 3.60 & 9 & 0.39 & 16.03 & 3.61 \\
\hline Spiraea mongolica & 4 & 0.34 & 10.33 & 3.47 & 2 & 0.39 & 0.65 & 0.52 \\
\hline Salix zhegushanica & 4 & 0.19 & 1.38 & 0.46 & 2 & 0.92 & 15.52 & 8.22 \\
\hline
\end{tabular}

$\mathrm{BCF}$ : The bioconcentration factor $(\mathrm{BCF})=\mathrm{C}($ root $) / \mathrm{C}($ soil); $\mathrm{TF}$ : Transfer factor $(\mathrm{TF})=\mathrm{C}($ shoot $) / \mathrm{C}$ (root).

Concentrations of arsenic and uranium in Polygonum viviparum and Rumex nepalensis were found to accumulate in the tissues of these two plant species. The highest uranium concentration was found in Rumex nepalensis at sample site R4 (178.60 mg× $\left.\mathrm{kg}^{-1}\right)$

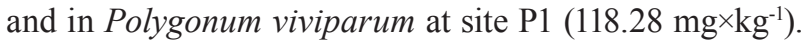
These high concentrations may be related to the location where these samples were collected adjacent to the open-pit mine. Uranium concentrations were also high, reaching $43.19 \mathrm{mg} \times \mathrm{kg}^{-1}$ for Rumex nepalensis and

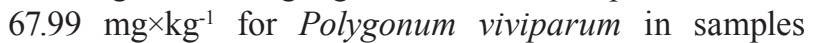
collected from sites P6 and R6, which were located by the tailings pond. Overall, arsenic and uranium concentrations in plant tissues were higher at sites near

Table 4. Characterization of arsenic accumulation in plant samples.

\begin{tabular}{|c|c|c|c|c|c|c|c|c|}
\hline \multirow{2}{*}{ Plant species } & \multicolumn{3}{|c|}{ BCF } & \multicolumn{3}{|c|}{ TF } \\
\cline { 2 - 9 } & N & Min & Max & Mean & N & Min & Max & Mean \\
\hline Anaphalis lactea & 8 & 0.02 & 0.31 & 0.14 & 3 & 0.28 & 1.35 & 1.07 \\
\hline Astragalus handelii & 5 & 0.07 & 0.20 & 0.12 & & & 0.84 & 0.14 \\
\hline Cirsium japonicum & 5 & 0.02 & 0.55 & 0.19 & 2 & 0.12 & 0.13 \\
\hline Cremanthodium lineare & 2 & 0.22 & 0.25 & 0.24 & & & 0.91 & \\
\hline Elymus dahuricus & 2 & 0.02 & 0.23 & 0.03 & & & 0.36 & \\
\hline Gentiana straminea & 2 & 0.10 & 0.17 & 0.13 & & & 1.73 & \\
\hline Herba Artimisiae & 4 & 0.01 & 0.34 & 0.16 & 3 & 0.25 & 14.45 & 5.25 \\
\hline Hippophae rhamnoides & 4 & 0.00 & 0.07 & 0.01 & 3 & 0.10 & 0.18 & 0.41 \\
\hline Lomatogonium rotatum & 2 & 0.01 & 0.06 & 0.03 & & & 30.52 & \\
\hline Leontopodium dedekensii & 8 & 0.01 & 1.00 & 0.26 & 2 & & 0.03 & 0.18 \\
\hline Polygonum viviparum & 8 & 0.04 & 0.49 & 0.18 & 7 & 1.00 & 3.69 & 2.04 \\
\hline Rumex nepalensis & 3 & 0.01 & 0.23 & 0.02 & 8 & 0.96 & 4.54 & 1.23 \\
\hline Spiraea mongolica & 4 & 0.03 & 0.31 & 0.11 & 2 & 0.20 & 0.80 & 0.50 \\
\hline Saussurea decurrens & 2 & 0.10 & 0.28 & 0.19 & & & \\
\hline Salix zhegushanica & 3 & 0.01 & 0.14 & 0.04 & 2 & 0.67 & 2.38 & 1.53 \\
\hline
\end{tabular}

$\mathrm{BCF}$ : the bioconcentration factor $(\mathrm{BCF})=\mathrm{C}($ root $) / \mathrm{C}($ soil $)$; $\mathrm{TF}$ : the transfer factor $(\mathrm{TF})=\mathrm{C}($ shoot $) / \mathrm{C}$ (root). 
mining activity than other sites. Arsenic accumulated to a lower level than uranium in both plant species. The accumulation of uranium in Rumex nepalensis was higher than Polygonum viviparum, but it was the contrary for arsenic, as arsenic and uranium accumulation in Polygonum viviparum were interconnected, but this was not found in Rumex nepalensis. Thus Rumex nepalensis is potentially suitable for removal of uranium and Polygonum viviparum can be used to remove for both arsenic and uranium (Fig. 4).

\section{Implications for Phytoremediation and Environmental Management}

Plant species distributions are formed by longterm adaptation and species-environment interactions. Phytoremediation areas had high uranium concentrations and radiation levels in our study. Most plant species were unable to grow under those conditions, with the exception of Polygonum viviparum and Rumex nepalensis, which became the dominant plant species in polluted areas. Polygonum viviparum was also located downstream on the $\mathrm{S}$ river, suggesting growth potential in wetland environments.

A study of the distribution of Rumex nepalensis and Polygonum viviparum may have allowed for more effective phytoremediation of arsenic and uraniumpolluted areas. One potential phytoremediation plan for the study area was shown in Fig. 5. Soil sampling analysis allowed for the identification of areas with arsenic and uranium contamination. Uraniumcontaminated areas included the artificial remediation areas, tailing pond and open-pit mining sites. The arsenic contaminated area covered the downstream stretch of the $\mathrm{S}$ river. In order to improve the efficiency of remediation, it is necessary to select suitable plants to grow in the contaminated areas. This study suggests that Rumex nepalensis and Polygonum viviparum are

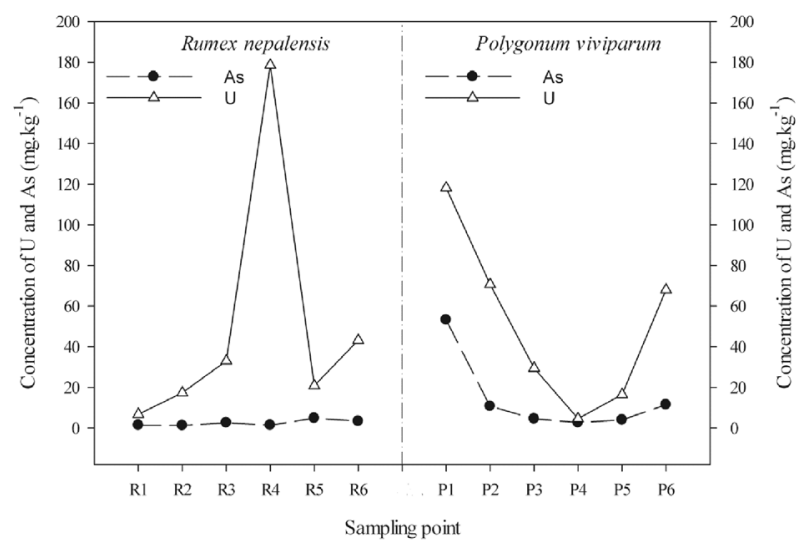

Fig. 4. Concentrations of arsenic and uranium $\left(\mathrm{mg} \cdot \mathrm{kg}^{-1}\right)$ in Rumex nepalensis and Polygonum viviparum samples collected from several different sites within the study area (Note:R1 to R6 represent some sampling points of Rumex nepalensis; P1 to P6 represent some sampling points of Polygonum viviparum). potentially useful in the remediation of arsenic and uranium-polluted areas. All individual plants sampled in this study grew in contaminated areas so that these species may be used as indicators of uranium, or combined uranium and arsenic, pollution in uranium ore sites ( Fig. 5).

In this study, an environmental assessment was conducted in order to provide environmental management guidelines for the Zoige uranium mine. For future remediation efforts, a multi-standard environmental risk assessment was commenced for the mine remediation area as a new technology in interdisciplinary biology and environmental science. Tailings ponds are ideally suited for the application of phytoremediation technology. For the artificial remediation area for the Zoige Mine, vegetation was planted on the hillside after the cessation of mining activities to stabilize the soil, but many planted species did not thrive in the polluted soils. This can be seen in descriptions of the artificial remediation area sites in Fig. 1. The reason for this failure was that the plant species were not selected specifically for heavy metal tolerance. In this study, uranium contamination was found to have produced a zone of strong radioactivity near the open-pit mine and plant species distributions were affected by this increase in radiation intensity [5960].

By investigating plant tissue samples for heavy metal accumulation, Polygonum viviparum and Rumex nepalensis were found to accumulate $\mathrm{U}$, and Polygonum viviparum for As accumulation [61]. At present, there is little information available on the use of Polygonum viviparum or Rumex nepalensis for the removal of As or U from polluted soils. Environmental factors, plant reproductive rates, germplasm resources and interactions among plant species may all form plant species distributions [62]. The following assessment of the extent of mine-associated pollution in this study, and investigation of the distributions of accumulator species, Polygonum viviparum and Rumex nepalensis were selected for As and $\mathrm{U}$ remediation in the study area.

Polygonum viviparum and Rumex nepalensis are also known for their heat-clearing and detoxification properties [63]. Thus, this study enhances our knowledge of heavy metal accumulation in these species and acts as a reference for the safety of herbal medicines. Furthermore, As- and U-accumulating species may be useful as bioindicators of soil pollution, and are attractive candidates for future environmental remediation efforts. Rumex nepalensis grew in soils with heavy uranium contamination, indicating that it is tolerant of the uranium-associated radioactivity. Meanwhile, Polygonum viviparum was found all around the study area revealing its suitability for arsenic remediation, even in wetlands such as that located downstream on the $\mathrm{S}$ river (Fig. 5). Rumex nepalensis is a common perennial herb that grows mainly in the northern hemisphere, but species in this 


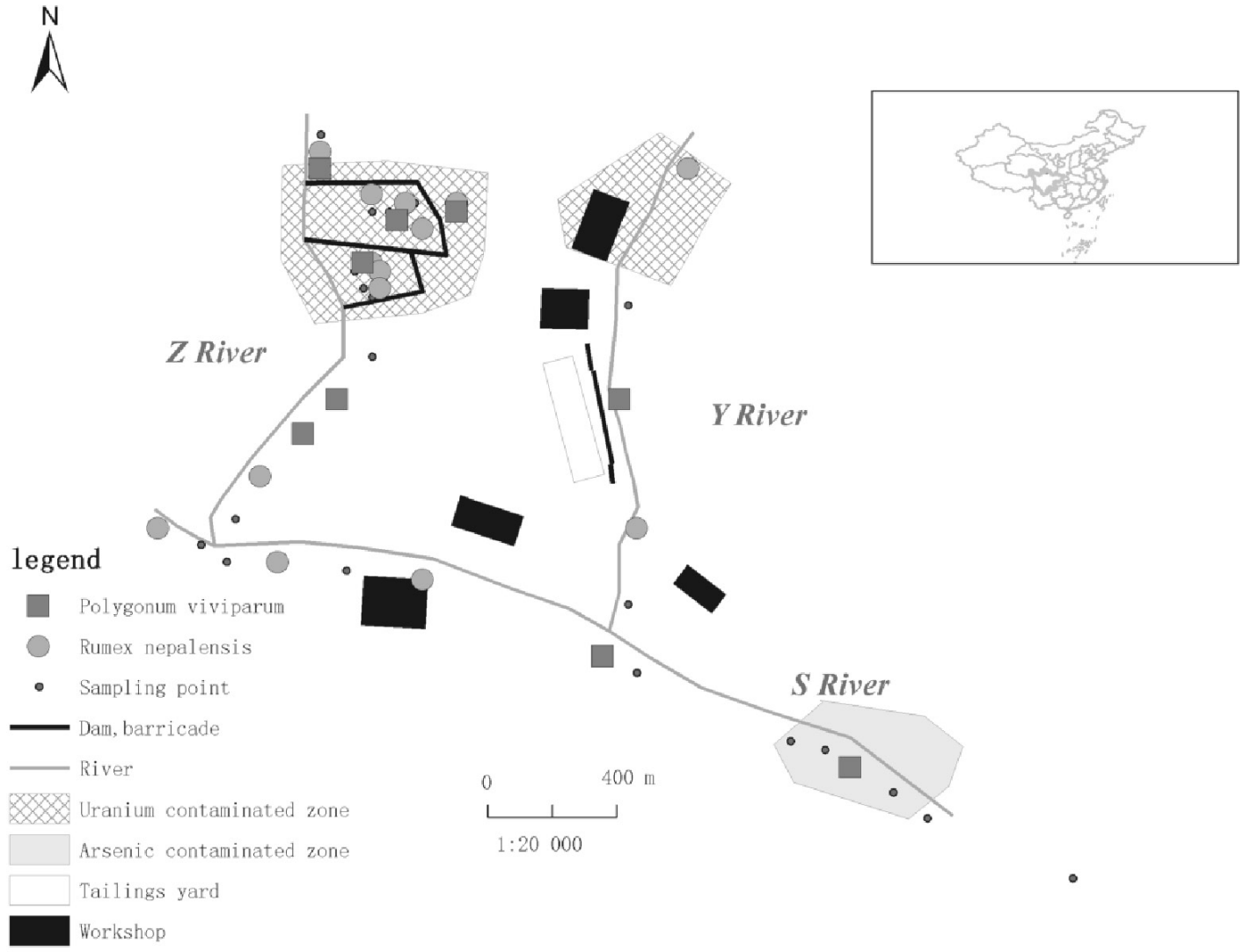

Fig.5. Phytoremediation plan for the sample area.

genus have been introduced almost everywhere [64]. Polygonum viviparum, commonly known as alpine bistort, grows in abundance in many different plant communities. Typical habitats include moist, short grasslands, yards, the edges of tracks and nutrient-rich fens [65]. Therefore, both Polygonum viviparum and Rumex nepalensis might be used for the treatment of arsenic and uranium pollution worldwide. This work has expanded the potential for phytoremediation of the Zoige Uranium Mine [66] (Table 2). It was the first study in which areas polluted with both arsenic and uranium were characterized, and the phytoremediation potentials of Polygonum viviparum and Rumex nepalensis were investigated. But the utility of these two plants species as phytoremediators may be partial depending on their ecological tolerances. For example, they may not be tolerant to desert-like conditions or be unable to survive freezing temperatures.

\section{Conclusions}

In this study, soil and plant samples were collected from 42 sample sites near the Zoige uranium mine. In addition, As and $U$ were quantified in the polluted mine soils, and the distributions of native plant species were mapped. The altitudinal distribution of heavy metal accumulator plants in the sample area and influencing factors were discussed. Uranium contamination was found in the open-pit mine located upstream on the $\mathrm{Z}$ river and in the mineral leaching area located upstream on the $\mathrm{Y}$ river. Arsenic contamination was found in downstream areas of the $\mathrm{S}$ river. Therefore, a censorious action is needed to take on metal pollution in this area. Anaphalis lactea, Rumex nepalensis, and Polygonum viviparum were uranium supper accumulators, whereas Cremanthodium lineare, Elymus dahuricus and Polygonum viviparum accumulated large amounts of As in proportion to their biomass. These species are imminently suitable for ecological remediation in the area. This study can serve as a reference for the phytoremediation of uranium mine pollution areas. However, further study of the long-term dynamics of phytoremediation is needed.

\section{Acknowledgments}

This study was supported by the Natural Science Foundation of China (41671244), the National Basic Research Program of China (CN: 2014CB846003) and the Longshan Academic Talent Research Support Program of SWUST (18LZX548). We express our thanks to the lab at the Southwest University of Science and Technology and to teachers, editors, and reviewers for their guidance and support. 


\section{Conflict of Interest}

The authors declare no conflict of interest.

\section{References}

1. KHAN N., ABAS N. Powering the people beyond 2050. Sci. Tech. Development. 31 (2), 133, 2012.

2. SINGH U.K., RAMANATHAN A.L., SUBRAMANIAN V. Groundwater chemistry and human health risk assessment in the mining region of East Singhbhum, Jharkhand, India. Chemosphere. 204, 501, 2018.

3. OLAWOYIN R., OYEWOLE S.A., GRAYSON R.L. Potential risk effect from elevated levels of soil heavy metals on human health in the Niger delta.Ecotoxicol. Environ. Saf. 85, 120, 2012.

4. MKANDAWIRE M., DUDEL E.G. Accumulation of arsenic in Lemna gibba L. (duckweed) in tailing waters of two abandoned uranium mining sites in Saxony, Germany. Sci.Total Environ. 336 (1-3), 81, 2005.

5. SINGH L., KUMAR R., KUMAR S., BAJWA B.S., SINGH S. Health risk assessments due to uranium contamination of drinking water in Bathinda region, Punjab state, India. Radioprot. 48 (2), 191, 2013.

6. MOLDOVAN B.J., JIM HENDRY M., HARRINGTON G.A. The arsenic source term for an in-pit uranium mine tailings facility and its long-term impact on the regional groundwater. Appl. Geochem. 23 (6), 1437, 2008.

7. MASU S., GRECU E., ONCIOIU I., PETRESCU M. For a sustainable development: Phytoremediation of oil-polluted soils by using birdsfoot trefoil crops. Rom. Biotech.Lett. 22 (6), 12010, 2016.

8. CHEN F., YAO Q., TIAN J.Y. Review of ecological restoration technology for mine tailings in China. Eng. Rev. 36 (2), 115, 2016.

9. MALAVIYA P., SINGH A. Phytoremediation strategies for remediation ofuranium-contaminated environments: A review. Cri. Rev. in Environ. Sci. Tech. 42 (24), 2575, 2012.

10. SELVAKUMAR R., RAMADOSS G., MENON M.P., RAJENDRAN K., THAVAMANI P., NAIDU R., MEGHARAJ M. Challenges and complexities in remediation of uranium contaminated soils: A review. J. Environ. Radio. 192, 592, 2018.

11. BHATTACHARYA S., GHOSH U.C. Environmental economic and health perspectives of arsenic toxicity in Bengal Delta. Wsn. 4, 111, 2015.

12. LAZARUS B.E., RICHARDS J.H., CLAASSEN V.P., O'DELL R.E., FERRELLerrell M.A. Species specific plant-soil interactions influence plant distribution on serpentine soils.Plant and Soil. 342 (1-2), 327, 2011.

13. SIRGUEY C., SEZNEC G., MAHEVAS T., ECHEVARRIA G., GONNEAU C., STERCKEMAN T. Soil trace metal content does not affect the distribution of the hyperaccumulator Noccaea caerulescens in the Vosges Mountains (France). Plant and Soil. 430, 245, 2018.

14. WANG C., CAO G., WANG Q., JING Z., DING L., LONG R. Changes in plant biomass and species composition of alpine Kobresia meadows along altitudinal gradient on the Qinghai-Tibetan Plateau. Sci. China Ser.C: Life Sciences. 51 (1), 86, 2008.

15. MKANDAWIRE M., TAUBERT B., DUDEL E.G. Resource manipulation in uranium and arsenic attenuation by Lemna gibba L. (duckweed) in tailing water of a former uranium mine. Water, Air Soil Poll. 166 (14), 83, 2005.

16. HUANG Z., TANG S., ZHANG L., MA L., DING S., DU L., XIA C. Interaction between $U$ and Th on their uptake, distribution, and toxicity in V S. alfredii based on the phytoremediation of U and Th. Environ. Sci. Pollut. R. 24 (3), 2996, 2017.

17. SILVA GONZAGA M.I., GONZAGA SANTOS J.A., MA L.Q. Arsenic phytoextraction and hyperaccumulation by fern species.Sci. Agr. 63, 90, 2006.

18. YILDIRIM D., SASMAZ A. Phytoremediation of As, $\mathrm{Ag}$, and $\mathrm{Pb}$ in contaminated soils using terrestrial plants grown on Gumuskoy mining area (Kutahya Turkey). J. Geochem. Explor. 182, 228, 2017.

19. DURUIBE J.O., OGWUEGBU M.O.C., EGWURUGWU J.N. Heavy metal pollution and human biotoxic effects. Int. J. phys. sci. 2 (5), 112, 2007.

20. MEYBECK M., LESTEL L., BONTE P., MOILLERON R., COLIN J.L., ROUSSELO T.O., THÉVENOT D.R. Historical perspective of heavy metals contamination $(\mathrm{Cd}, \mathrm{Cr}, \mathrm{Cu}, \mathrm{Hg}, \mathrm{Pb}, \mathrm{Zn})$ in the Seine River basin (France) following a DPSIR approach (19502005). Sci. Total Environ. 375 (1-3), 204, 2007.

21. CORTESE A.D. Education for an environmentally sustainable future.Environ. Sci. \& Tech. 26 (6), 1108, 1992.

22. HE Z., SHENTU J., YANG X., BALIGAR V.C., ZHANG T., STOFFELLA P.J. Heavy metal contamination of soils: sources, indicators and assessment. J. Environ. Indic. 9, 17, 2015.

23. LI Z., MA Z., VAN DER KUIJP T.J., YUAN Z., HUANG L. A review of soil heavy metal pollution from mines in China: Pollution and health risk assessment. Sci. Total Environ. 468-469C, 843, 2013.

24. QING X., YUTONG Z., SHENGGAO L. Assessment of heavy metal pollution and human health risk in urban soils of steel industrial city (Anshan), Liaoning, Northeast China. Ecotoxicol. Environ. Saf. 120, 377, 2015.

25. HUANG X., HU J., LI C., DENG J., LONG J., QIN F. Heavy-metal pollution and potential ecological risk assessment of sediments from Baihua Lake, Guizhou, P.R. China. Int. J. Environ. Health Res. 19 (6), 405, 2009.

26. MAANAN M., SADDIK M., MAANAN M., CHAIBI M., ASSOBHEI O., ZOURARAH B. Environmental and ecological risk assessment of heavy metals in sediments of Nador lagoon, Morocco. Ecol. Ind. 48, 616, 2015.

27. WANG Y., HU J., XIONG K., HUANG X., DUAN S. Distribution of heavy metals in Core Sediments from Baihua Lake. Procedia Environ. Sci. 16, 51, 2012.

28. MAZUREK R., KOWALSKA J., GASIOREK M., ZADROZNY P., JOZEFOWSKA A., ZALESKI T., ORLOWSKA K. Assessment of heavy metals contamination in surface layers of Roztocze National Park forest soils (SE Poland) by indices of pollution. Chemosphere. 168, 839, 2017.

29. LUO L., LIU M.X., DONG F.Q. Speciation distribution characteristics of heavy metals inthe soil of multi-metal mining pastoral area and pollution assessment. J. AgroEnviron. Sci. 35 (8), 1523, 2016.

30. PENG M., YE J., HE Z. Information analysis of vegetation pollution in uranium tailings based on hyper spectral data. Geosp. Inf. 13 (01), 111, 2015. https://doi:10.3969/j. issn.1672-4623.2015.01.037 [In Chinese]

31. RICHTER N., STAENA K., KAUFMANN H. Spectral unmixing of airborne hyperspectral data for baseline mapping of mine tailings areas. Int. J. Remote Sens. 29 (13), 3937, 2008. 
32. ZHANG X., LIU H., BAKER C., GRAHAM S. Restoration approaches used for degraded peatlands in Ruoergai (Zoige), Tibetan Plateau, China, for sustainable land management. Ecol. Eng. 38 (1), 86, 2012.

33. FAVAS P.J.C., PRATAS J., MITRA S., SARKAR S.K., VENKATACHALAM P. Biogeochemistry of uranium in the soil-plant and water-plant systems in an old uranium mine. Sci. Total Environ. 568, 350, 2016.

34. HE Z., CHEN Y., CHANG D., WEI J., HU X. Geochemical characteristics of trace element of calcite, quartz of the No. 510-1 Uranium Ore Deposit in Zoige. Acta Geol.Sin. (Eng. Ed). 88 (s2), 1105, 2014.

35. ZHANG X., SUN H., ZHANG Z., NIU Q., CHEN Y., CRITTENDEN J.C. Enhanced bioaccumulation of cadmium in carp in the presence of titanium dioxide nanoparticles. Chemosphere. 67 (1), 160, 2007.

36. ZHONG W.S., REN T., ZHAO L.J. Determination of Pb (Lead), $\mathrm{Cd}$ (Cadmium), $\mathrm{Cr}$ (Chromium), $\mathrm{Cu}$ (Copper), and $\mathrm{Ni}$ (Nickel) in Chinese tea with high-resolution continuum source graphite furnace atomic absorption spectrometry. J. Food Drug Anal. 24 (1), 46, 2016.

37. ZHAO H., WANG X., LIX. Quantifying grain-size variability of metal pollutants in road-deposited sediments using the coefficient of variation.Int. J. Environ. Res. Pub. Health. 14 (8), 850, 2017.

38. HUANG S.W., JIN J.Y. Status of heavy metals in agricultural soils as affected by different patterns of land use. Environ. Monit. Assess. 139 (1-3), 317, 2008.

39. JORFI S., MALEKI R., JAAFARZADEH N., AHMADI M. Pollution load index for heavy metals in mian-ab plain soil, Khuzestan, Iran. Dat. Brief. 15, 584, 2017.

40. BONANNO G., RACCUIA S.A. Seagrass Halophila stipulacea: capacity of accumulation and biomonitoring of trace elements. Sci. Total Environ. 633, 257, 2018.

41. ARUMUGAM G., RAJENDRAN R., GANESAN A., SETHU R. Bioaccumulation and translocation of heavy metals in mangrove rhizosphere sediments to tissues of Avicenia marina - A field study from tropical mangrove forest. Environ. Nanotech. Monit. Manag. 10, 272, 2018.

42. PLANT J.A., REEDER S., SALMINEN R., SMITH D.B., TARVAINEN T., DE VIVO B., PETTERSON M.G. The distribution of uranium over Europe: geological and environmental significance. Appl. Earth Sci. 112 (3), 221, 2003.

43. YANG G., DONG F., LIU M., NIE X., ZONG M., PENG C., ZHANG W. Interactive effect of radioactive and heavymetal contamination on soil enzyme activity in a former Uranium mine. Pol. J. Environ. Stud.27(3), 1343, 2018.

44. 44. YANG G., WANG M., CHEN H., LIU L., WU N., ZHU D., HE Y. Responses of $\mathrm{CO}_{2}$ emission and pore water DOC concentration to soil warming and water table drawdown in Zoige Peatlands. Atmos. Environ.152, 323, 2017.

45. 45. FATIMA S., HUSSAIN I., RASOOL A., XIAO T., FAROOQI A. Comparison of two alluvial aquifers shows the probable role of river sediments on the release of arsenic in the groundwater of district Vehari, Punjab, Pakistan. Environ. Earth Sci. 77 (10), 382, 2018.

46. SATHE S.S., MAHANTA C., MISHRA P. Simultaneous influence of indigenous microorganism along with abiotic factors controlling arsenic mobilization in Brahmaputra floodplain, India. J. Contam. Hydrol. 213, 1, 2018.

47. PENG H., HAN F., WANG H., SHI S., SHEN J., ZHOU D. Characteristics of seasonal and altitude variation of UV-absorbing compounds content in three alpine plants on
Qinghai-Tibet Plateau. Acta Botan. Boreal.-Occident. Sin. 30 (6), 1197, 2010.

48. HAGEMEYER J. Plants as Biomonitors: Indicators for heavy metals in the terrestrial environment. Bernd Markert, New York. 6, 178, 1993.

49. MRTÍNEZ-RUIZ C., MARRS R.H. Some factors affecting successional change on uranium mine wastes: Insights for ecological restoration. Appl. Veg. Sci. 10 (3), 333, 2007.

50. SOUZA L.A., PIOTTO F.A., DOURADO M.N., SCHMIDT D., FRANCO M.R., BOARETTO L.F., AZEVEDO R.A. Physiological and biochemical responses of Dolichos lablab L. to cadmium support its potential as a cadmium phytoremediator.J. Soils Sed. 17 (5), 1413, 2017.

51. MARKERT B. Establishing of "Reference Plant" for inorganic characterization of different plant species by chemical fingerprinting. Water, Air, \& Soil Poll. 64 (3-4), 533, 1992.

52. LAM E.J., CÁNOVAS M., GÁLVEZ M.E., MONTOFRÉE Í.L., KEITH B.F., FAZ Á. Evaluation of the phytoremediation potential of native plants growing on a copper mine tailing in northern Chile. J. Geochem. Explor. 182, 210, 2017.

53. TOUCEDA-GONZÁLEZ M., ÁLVAREZ-LóPEZ V., PRIETO-FERNÁNDEZ., RODRÍGUEZ-GARRIDO B., TRASAR-CEPEDA C., MENCH M., KIDD P.S. Aided phytostabilisation reduces metal toxicity, improves soil fertility and enhances microbial activity in $\mathrm{Cu}$-rich mine tailings. J. Environ. Manag. 186, 301, 2017.

54. SUBHASHINI V., SWAMY A.V.V.S., KRISHNA R.H. Pot Experiment: To study the uptake of zinc by different plant species in artificially contaminated soil. World J. Environ.Eng. 1 (2), 27, 2013.

55. LIANG S., XUAN Y., LIU W., LI X., SHEN S.,GANG DING L. Feasibility of $\mathrm{Pb}$ phytoextraction using nano-materials assisted ryegrass: Results of a one-year field-scale experiment. J. Environ. Manag. 190, 170, 2017.

56. KUMAR V., SHARMA A., DHUNNA G., CHAWLA A., BHARDWAJ R., THUKRAL A.K. A tabulated review on distribution of heavy metals in various plants. Environmental Sci. Pollut. Res. 24 (3), 2210, 2017.

57. ANTONIADIS V., SHAHEEN S.M., BOERSCH J., FROHNE T., DU LAING G., RINKLEBE J. Bioavailability and risk assessment of potentially toxic elements in garden edible vegetables and soils around a highly contaminated former mining area in Germany. J. Environ. Manag. 186, 192, 2017.

58. MANDAL A., PURAKAYASTHA T.J., PATRA A.K., SARKAR B. Arsenic phytoextraction by Pteris vittata improves microbial properties in contaminated soil under various phosphate fertilizations. Appl. Geochem. 88, 258, 2018.

59. ZONG M.R., DONG F.Q., LIU M.X., YANG G., ZHANG Q., HOU L., LUO Z. A detailed investigation on the environmental effect of an uranium mine in Western China including $\gamma$-ray radiation formation and microbe distribution. J. Nanosc. Nanotech. 17 (9), 6614, 2017.

60. DAWSON S.P., DENNISON W.C. Effects of ultraviolet and photosynthetically active radiation on five seagrass species. Mar. Biol. 125 (4), 629, 1996.

61. LU C., WANG Y., YANG J. Soil heavy metal pollution and dominant plants selection in $\mathrm{Pb}-\mathrm{Zn}$ mining areas of Guangxi. Chin. J. Soil Sci. 41 (6), 1471, 2010. 
62. SILVERTOWN J., ARAYA Y., GOWING D. Hydrological niches in terrestrial plant communities: A review. J. Ecol. 103 (1), 93, 2015.

63. WANG Y., HE W., HUANG H., AN L., WANG D., ZHANG F. Antioxidative responses to different altitudes in leaves of alpine plant Polygonum viviparum in summer. Acta Physiol. Pl. 31 (4), 839, 2009.

64. O'NEILL A.R., BADOLA H.K., DHYANI P.P., RANA S.K. Integratingethnobiological knowledge into biodiversity conservation in the Eastern Himalayas. J. Ethnobiol. Ethnomed. 13 (1), 21, 2017.

65. DIGGLE P.K. Extreme preformation in alpine Polygonum viviparum: an architectural and developmental analysis. Am. J. Bot. 84 (2), 154, 1997.

66. YAO Y., ZHANG B. The mass elevation effect of the Tibetan Plateau and its implications for alpine treelines. Int. J. Climatol. 35 (8), 1833, 2015. 
